\title{
19世紀から20世紀の RIBA に所属した建築家の世界分布とその背景 WORLD DISTRIBUTION OF THE RIBA ARCHITECTS FROM THE 19TH TO THE 20TH CENTURY AND THEIR BACKGROUNDS
}

\author{
鮎川 慧* \\ Kei AYUKAWA
}

\begin{abstract}
The purpose of this paper is to consider the architectural relations and interactions between and within regions all over the world from the 19th to the 20th century by analyzing the transmigration and interactions of RIBA architects.

The methods are as follows

1. To look over the official RIBA member lists and pick up all the members who worked outside Britain from 1834 to 1939

2. To clarify their temporal world distribution and the background of the transmigrants

3. To regard RIBA architects as a cluster and consider their trend
\end{abstract}

Keywords : Modern times, British Empire, RIBA, transmigration of Architects, world distribution 近代，イギリス帝国，RIBA，建築家の移動，世界分布

\section{1. 本研究の目的}

グローバリゼーションがす寸む現在、世界の建築は、建築家の移 動、建築メディアによる建築情報の移動、開発資本の移動等によって、 日々大きく変動している。この状況は、交通や電信技術の飛躍的な 進歩により世界中に定期航路や電信ケーブルが張り巡らされ、ヒト、 モノ、カネ、情報が国境線を越えて行き交うという状況が始まった 19 世紀に端を発する注1)。現在の建築世界のグローバリゼーションの 発端のひとつには、この時代の西洋近代世界の拡大とそれに伴う建 築知の移動をあげることができる。

本研究は、この時代に世界へと活動の場を広げた王立英国建築家協 会 (Royal Institute of British Architects、以下 RIBA) 会員の動きを 通して、各地域の建築世界を相対化し、連結させる視点を獲得する ことを目的とする。非領域的な諸関係が錯綜する現代社会の理解を 深めるためには、国家といった政治領域的な枠組みをはずし、アジ アと西洋、さらにアジアと世界、アジアとアフリカをむ寸びつける 多角的なチャンネルを、建築史を通して用意することが必要である。 19 世紀、20 世紀の RIBA 会員たちの動きや活動の相関関係は、その 一つ一つを構成している。具体的には、RIBA 会員の世界的な分布と 移動を群で捉え、既往研究より一段マクロなレベルで分析すること で、各地域の建築世界を俯瞰し、今まで論じられてこなかった建築 世界を一体的に論じる視点を提示したい。

\section{2. 研究方法と先行研究}

研究対象とするのは、RIBA 会員のうち、19 世紀から 20 世紀にか けてイギリス本国以外で現地の設計活動や教育活動に携わった建築 家である。

対象時期は、RIBAの設立された 1834 年から、イギリス帝国が世
界中で覇権を確立していた第二次世界大戦前までに設定する。イギ リス帝国は 19 世紀から 20 世紀初頭にかけて帝国領土内のみならず 世界中で覇権を行使していた。しかし第一次世界大戦後に領土は最 大となるものの、軍事・安全保障面での影響力が低下しはじめ、覇 権はアメリカ合衆国へと移っていく注2)。本研究ではイギリス人社会 の世界への拡大と彼らの持つ建築に関する技術や知識の拡大に注目 するため、対象時期を上記に設定する。またイギリス本国を、イン グランド、ウェールズ、スコットランド、アイルランド、マン島を 含むブリテン諸島と定義する注 3 。

利用した資料は、ロンドンの RIBA 本部の図書館と大英図書館に所 蔵されている創立当初からの年次報告書 (RIBA Kalender)、会員の 資格審査書類 (Nomination Paper) および定期刊行雑誌や論文集であ る。そして設立当初から 1939 年までの会員名簿注4) から、登録住所 がイギリス本国以外になっている会員をすべてピックアップし、年 別に氏名、滞在都市、RIBA における会員区分注5)、所属を中心にリ スト化して分析した。

先行研究としては、RIBA の協会史注 6) があるが、これは協会の内 側から見た歴史であるため、海外に出て行った建築家のことなどは 全く無視されており、協会のアジアにおける意味なども全く描かれ ていない。

RIBA 建築家の海外における活動を対象にした研究では、世界全体 を捉えたものは見当たらない。しかし地域毎のイギリス人建築家に 関寸る研究はいくつかあり、南アフリカに関してはサリー・メイ・ ブラウン (Brown, Sally May) の研究注7)、東アジアに関しては泉田英 雄の一連の研究注8) があげられる。しかしながらどちらも建築家を孤 立した点として捉え、ローカルな視点で歴史を描いており、彼らと 世界全体との関係については議論の余地が大きく残されている。 
他にイギリス帝国の建築活動に関する研究は、都市史や個別の建築 史、建築家個人に関寸るものが数多くある。イギリス本国ばかりで なく、植民地であったインド、オーストラリア、ニュージーランド、 カナダ、南アフリカなどでも、個別の建築家の業績について研究が 進んでいる注 9)。

\section{RIBA の設立と建築家の職能の確立}

RIBA 会員の分析に入る前に、RIBA という組織の歴史とそれが果 たした役割について概括しておく。

まず RIBA は、1834 年に設立された英国建築家協会 (Institute of British Architects、以下、IBA）を前身とする、イギリスにおける建 築家に関する最も古い職能団体のひとつである。1837 年に英国王室 の勅許を受け、1866 年に名称も現在と同じ RIBA となった注 10$)$ 。設 立された翌 1835 年は 122 名で構成され、有資格会員 (Licentiate) の募集が始まった 1909 年からは 4000 人台を推移し、第一次世界大 戦後に急増し、1939 年には 9141 名となった。しかし現在もそうで あるように、当時からイギリスにおいて建築家を自称する者全員が RIBA に所属していたわけではなく、1841 年には国勢調査に記録さ れている 1675 人の建築家のうち RIBA 会員は 153 人、1891年には 7842 人の建築家のうち 1344 人に過ぎなかった注11)。

次に、RIBA が果たした役割は次の三つに絞ることができる。

まず一つ目の大きな役割は、イギリス本国における建築家の職能 の確立である。現在のイギリスでは、建築業に携わる技術者には建 築家 (Architect) だけでなく、調查士 (Surveyor)、土木技術師 (Civil Engineer) など複数の職能が存在する。これらの職能は 19 世紀の 時点ではまだ完全に独立しておらず、18 世紀末になって、建築デ ザイン業務とその他の業務に携わる専門家を分離させようという 動きが出てくる注 12)。その動きの中、まず 1791 年に建築家クラブ (Architects' Club) が設立されたが、この団体は加入者が限られ、活 動は社交クラブ的な性格が強く、社会に強い影響力を持たなかった 注13)。その後いくつか設立された団体のなかでも大きな影響力をもっ ていたのが IBA である。その設立は「建築の発展と振興をはかり、 建築に関連する様々な芸術や科学の諸分野を振興し、その知識の修 得を促進すること」注 14)を目的としており、学術的活動に重点を置 いて1831年に設立された建築協会 (Architectural Society)に比べて、 より職能的性格を強めていた注 15$)$ 。土木技師や調査士の職能団体も それぞれ 1818 年、1 1868 年に設立されており、19 世紀は建築家や土 木技術者、調查士たちの職能が、互いに干渉しながらゆるやかに確 立していった時代であったといえる。その中で RIBA は建築協会な ど建築に携わる他のいくつかの専門家組織と合併を繰り返しながら、 建築家の職能団体の中心的な存在として力を強めていったのである。 二つ目の役割は、イギリス本国内外での建築の体系的な教育制度の 確立である。それまで建築家は徒弟制度によって養成されるのが一 般的であったが注 16)、RIBA は「体系的な職業教育の発展」注 17) を目 指し、建築家の資質を図る試験制度を 1863 年から導入した。RIBA は教育に直接関わりはしなかったが、この試験は当時確立されつつ あった大学での建築教育の水準を担保する役割を果たし、1931 年以 降になると建築家登録する際の資格試験へとその役割を変えていく。 1902 年からは RIBA 公認の大学を卒業することで何段階かの試験を 免除されるというシステムを設け注18)、帝国内のいくつかの大学にも、
本国と同じように適用した。1930 年代までに本国外で認定された大 学は、ボンベイ、モントリオール、トロント、シドニー、マニトバ、 ヨ八ネスブルグ、ケープタウン、オークランド、メルボルンの数十 の大学にのぼる。さらにこれらの大学にはランク付けが行われ注 19)、 認定を受けた大学はイギリス本国での建築家の基準に合わせた教育 を行うこととなった。このようにしてRIBA は世界の大学をRIBA を中心に据えた試験システムに組み込みながら、大学を基盤とした 建築家養成の場を帝国内一と浸透させたのである。つまり RIBA は、 単に試験を通して体系的な職業教育を発展させたのみならず、大英 帝国の主な場所やその影響圈へ、自らを中心に据えた権威付けを行 いながら、教育制度そのものを拡散させる役割を持っていたといっ ていいだろう。

三つ目の役割は、帝国内での建築家の職能団体の設立である。会員 たちは、帝国各地でいくつかの建築家の職能団体の設立に携わって いる。1 871 年にはオーストラリアのメルボルン、1899 年には南ア フリカのケープで建築家協会を設立しており、その後もカナダや海 峡植民地、インドなど、各地で協会の設立に直接、間接的に関わった。 そしてさらに各地の建築家協会を、RIBA の広げる連合協会 (Allied Society) というネットワークに組み込んでいった。これは 1889 年に 始まった、RIBA とイギリス国内外の建築家協会が同盟を結ぶシス テムである注20)。初年度には本国の 9 つの協会が連合協会に認定され ている。そして 1893 年のオーストラリアのニュー・サウス・ウェ ールズ建築家協会 (The Institute of Architects of New South Wales) との連合を皮切りに、他の海外の協会にも連合が結ばれ、1939 年に はアフリカ、オーストラリア、ニュージーランド、カナダ、インド、 海峡植民地の合計 22 の建築家協会が本国外で連合協会となってい る。1921 年以降はそれぞれの協会の代表は年に 3 回ロンドンで集ま ることになり注 21 、各協会は各地域の建築界で中心的存在として、ロ ンドンと各地域を結ぶ役割を果たすこととなった注22)

以上のように 19 世紀から 20 世紀前半の RIBA は、建築家の職能 の確立とともに、建築教育制度の確立と帝国全体に広がる建築家の 認定システムの整備、帝国内を中心とした各地の建築家の職能団体 の成立の後押し、あるいは担う役割を持っていたと考えていいだろ う。そしてそうしてできた教育・認定・職能に関する組織や制度は、 ロンドンを中心としたネットワークに組み込まれていったのである。 しかしながらこれはイギリス本国の RIBA を主体として見た時の流 れにすぎず、世界全体でのそれぞれの地域の協会や制度の総体的な 関係についてはわからない。以下では世界全体の建築界を横断的に 論じる視点に立ち、RIBA 会員の個別の動きを数量ベースで議論を すすめたい。

\section{4. 会員の世界分布}

RIBA 会員の名簿を分析した結果、RIBA 設立の 1834 年から 1939 年までにイギリス本国外に滞在した会員数は全部で 2094 人であっ た ${ }^{23}{ }^{23)}$ 。図 1 は RIBA の全会員数と海外滞在会員数、会員全体に占 める海外滞在者の割合を示したものである。この図の棒グラフは海 外滞在会員数を会員区分別に示し、折れ線グラフの点線は RIBAの 全会員数、実線は全 RIBA 会員に占める海外滞在者の割合を示して いる。海外滞在会員は第一次世界大戦で減少するものの、その後再 び増加し、1920 年代後半以降は 800 人台を推移する。全会員に占め 
る割合も年を経るごとに増え、第一次世界大戦後には $12 \%$ 前後とな っている。

このグラフの海外滞在会員数の増減に注目すると、設立からのお よそ 100 年間における RIBA 会員の海外進出は、大きく 3 期に分け て考えることができる。第 I 期は、RIBA 会員自体は増加している が海外在住者はほとんど増加せず $2 \%$ 前後を推移する 1854 年から 1882 年、第 II 期は海外在住者が増加し $7 \%$ 台を推移する 1883 年か ら 1908 年、第正期は急激に増加し $12 \%$ 前後を推移する 1909 年か ら 1939 年である。

それぞれの地域での人数の推移を図 2 に示寸。会員は帝国の領土ば かりではなく、アルゼンチンやチリ、ボルネオなどの非公式植民地 と呼ばれる影響圈にも多く分布しており、特に初期ほど帝国内滞在 者が多い傾向にある。RIBA 会員以外にも各都市で建築関係の職に 就く人はたくさんいたため、会員数から都市の建設規模を直接推し 量ることはできないが、会員の多さはそれだけ事業、特に西洋建築 の建設事業があったことを示唆しており、当時の都市のいわゆる近 代化の規模や推進度を推測することはできる。全体を通じて会員数 が多いのは、カナダ、オーストラリア、ニュージーランドの自治領 と呼ばれる白人定住地で、全海外滞在者数の $53.8 \%$ を占める。さら に南アフリカも含めると自治領滞在者は $72.3 \%$ にのぼる。アジアに は全海外滞在者のうち $21.5 \%$ が滞在していた。しかし 19 世紀を通 じてイギリスからの移民が最も多かったアメリカに滞在した会員は $5 \%$ に満たない注24)。アメリカでは他の地域に比べて比較的早い 1857 年に建築家協会が成立しており、既にイギリス人以外の建築家が存 在していたためであろう注 25)。海外で活動した会員たちは、RIBA 会 員であること、そして正統な建築家であることの強みを持って、現 地での建設活動にあたっていたものと思われる。

この分布地とその人数の変遷と会員の移動パターンから、何が読み 解けるだろうか。以下に、各時期別に分析をす寸める。

\section{$4-1$. 第 I 期}

第 I 期は会員が初めて世界へ出た 1854 年から、会員数が緩やかに 上昇を続ける 1882 年までの期間である。この期間に海外に滞在し
た会員 59 人中、過半数の 34 人が向かったのは、ヨーロッパ、オー ストラリア、ニュージーランド、カナダの白人定住地である。他に はカイロ、シエラレオネ、ケープタウンに 9 人、ボンベイ、マドラス、 カルカッタに 9 人、シンガポール、上海、香港、東京に 7 人、バル パライソ、モンテビデオに 2 人となっている注 26$)$

初めての会員は 1854 年にパリに現れ、その後 4 年間はパリ以外に は現れない。そして 1858 年にメルボルン、1860 年にアデレード、 1863 年にオタワといった白人定住地に現れ、それらの都市で人数が 増える。非白人定住地には 1864 年のボンベイを皮切りに、1869 年 にバルパライソ、1873 年にカイロと香港、1874 年に南アフリカの ケープタウンに現れ、五大陸へと活動の場を広げていく。その後徐々 に東・東南アジアにも広がりを見せ、1876 年に上海、1 877 年に東 京、 1879 年にシンガポール、1884 年にセランゴールへとやってき ている注27。。アジアにRIBA 会員がやってきた 1860 年代以降は、ヨ 一ロッパからの蒸気船による定期航路が次々に開設された時代であ り、1880 年代になると、インド洋や極東の海域にもイギリス系の汽 船定期航路が網の目のように張り巡らされるようになっていた注28)。

また彼らの所属を分析した結果、多くは現地の公的建築組織に所属 するのではなく、民間の組織に所属、あるいはフリーの建築家とし て活動していたことがわかった注29)。

さらに海外に向かった時の彼らの年齢に注目すると、白人定住地一 向かった会員の平均年齢は 38.3 歳であるのに対し、非白人定住地一 向かった会員は 30.5 歳とかなり若くなっていた注30)。この時期の非 白人定住地の会員の多くは、その若さにも関わらず現地で初めての 「正統な建築家」として、民・官多数の建築設計を手掛けている。例 えばこの時期に工部大学校で教鞭をとるべく来日したジョサイア・ コンドルは当時 25 歳であった。彼は日本にやってきたことで、本 国の同年代の建築家たちに比べて大規模な民・官の建築を手がける チャンスを得た。日本側から見れば RIBA の若手建築家最高の賞で あるソーン賞を受賞しただけで本国にまだ実作のない若手建築家を 雇うというリスクは、RIBA という組織への信頼によって担保され ていた。コンドルからすれば、極東へ行くというリスクは負うが、

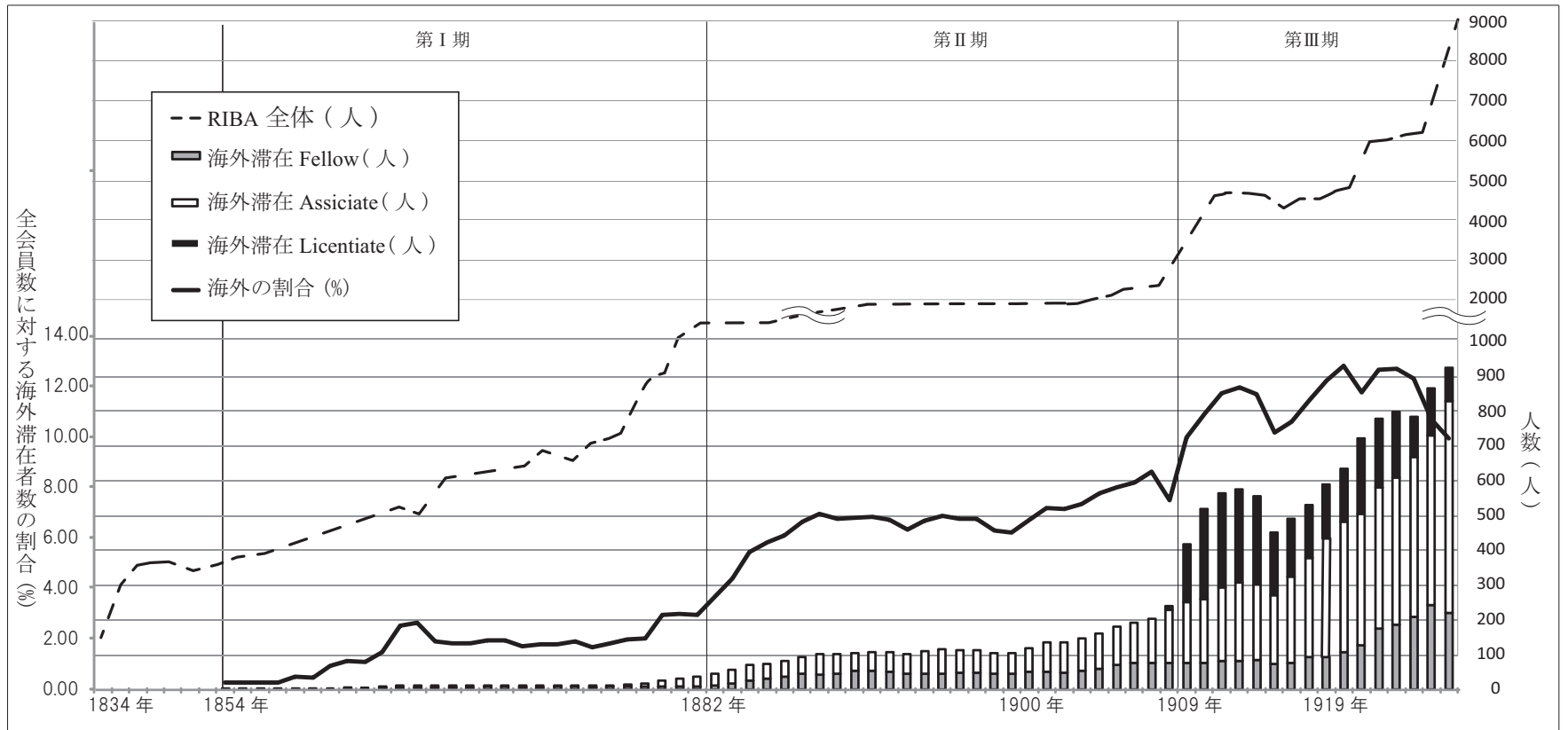

図 1 RIBA 会員の人数変化 


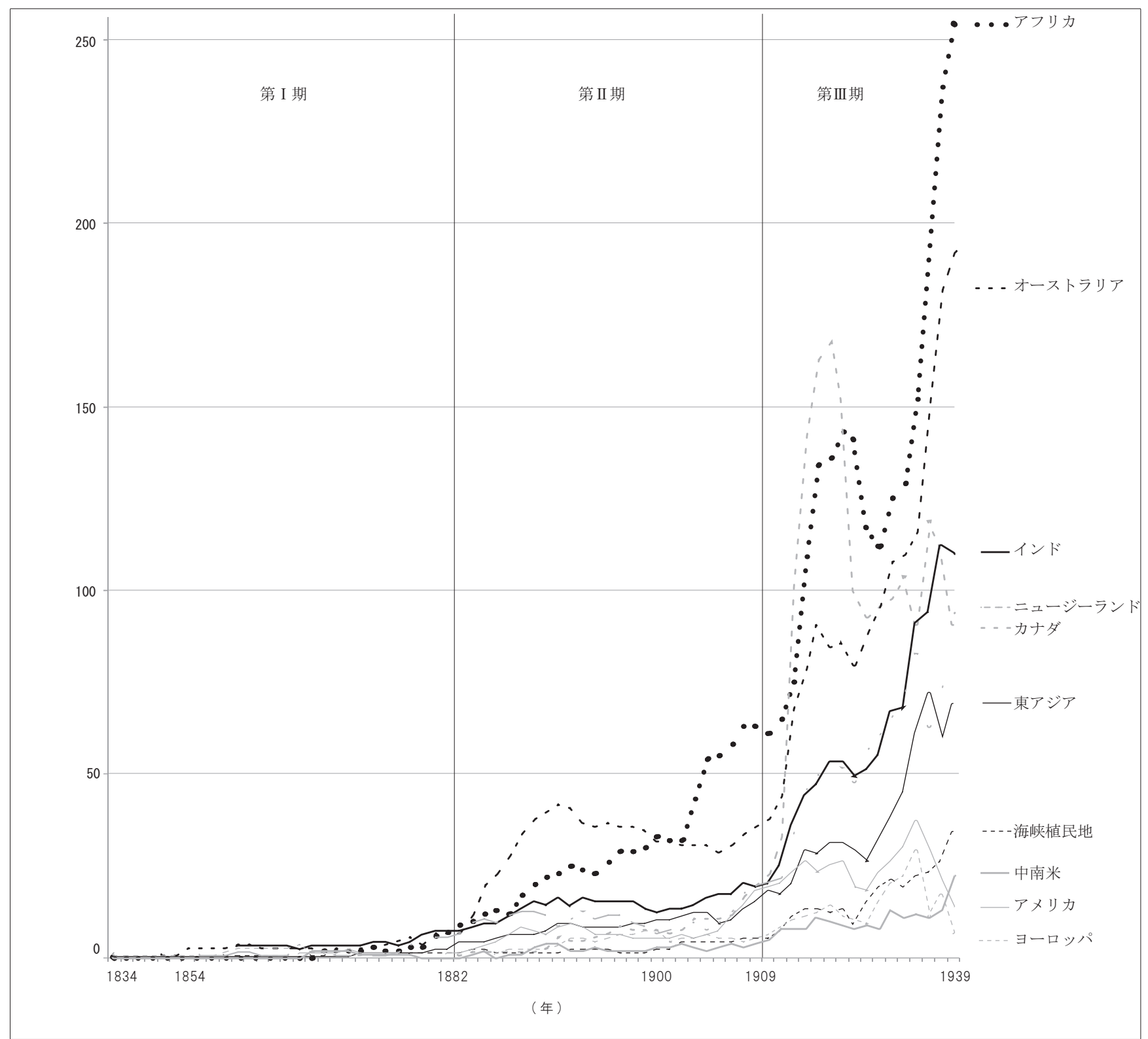

図 2 世界各地域での会員数の変化

RIBA の後ろ盾を得ることで日本側の信頼を得ることができ、華々 しいデビューを飾れたと考えてもいいだろう。

以上から、初期の RIBA 建築家たちは大きくは白人定住地から非 白人定住地へ、そして徐々に世界中の主要都市へと広がり、そこを 拠点に活動を行っていたことが分かる。また滞在先の都市は、白人 定住地を除けば、イギリス帝国の影響圈やアジアの開港地の傾向が 高い。さらに非白人定住地で活動するのは若手建築家に多く、異な る背景をもつ建築家とクライアントが出会う際のリスクとチャンス を補填して建設を促す触媒として、この時期の RIBA が存在してい たといえるだろう。

\section{4-2. 第 II 期}

第 II 期は海外滞在者数とともに全会員に占める割合が増加した 1883 年から 1908 年である。図 2 で滞在地別の内訳を見てみると、 この時期の会員数増加は、オーストラリアとアフリカに滞在した会 員によってけん引されていたことがわかる。

まず 1880 年代から会員数が急増するのは、オーストラリアである。
1870 年には 3 人だったオーストラリアの会員は、 1890 年には 39 人 へと急増している。この時期の滞在都市はシドニーとメルボルンで あり、その他にはパース、ブリスベン、アデレード、タスマニアな ど沿岸部の大都市にも少数の会員がみられる。この時期にオースト ラリアに会員が押し寄せた原因は、同時期の自由移民の増加と、そ れに伴う都市開発が考えられる。オーストラリアは 18 世紀末のシド ニー占有以降にイギリスの支配下に入るが、1853 年に流刑植民地制 度が廃止されるまで、イギリス本国でのそのイメージは移民を奨励 するものではなかったが注31)、イギリスからの移民は 1850 年代から 急増し、乱高下しながらも 1880 年代には 340,339 人にのぼってい る注32)。シドニーやメルボルンで現在も残る主だった公共建築が建設 されたのはこの時期であり注 33) 、増加するイギリス人社会の建設需要 に応じるかのように、RIBA 会員はこの時期にオーストラリアで増 加しているのである。そしてオーストラリアでの会員数は 1892 年 にピークとなった後、本国へ帰国した会員が相次ぎ、減少した。本 国からの自由移民も 1890 年代には 99,652 人に減少しており注 34 、 
会員の減少も自由移民数の波と足並みがそろっている。

次に 1900 年代に入って会員数が増加するのが、南アフリカである。 南アフリカは 1814 年のウィーン会議で正式にイギリス領となったも のの、1890 年代までは地理学および医学上の問題によってヨーロッ パ人の進出が阻まれていた注35)。1 1815 年から 1914 年にかけてケー プ植民地とナタールにやってきた移民は、イギリスからの全移民の うち $3.4 \%$ を占めていたにすぎない。しかし世紀転換期をはさんで急 増し、1900 年からの 10 年間には、その直前の 10 年間のおよそ 5 倍 にあたる 447,120 人がイギリスから南アフリカへ移住している注 36 。 RIBA 会員が増えたのもこの時期に一致する。

ただしこの時期はアメリカやカナダへの自由移民数も非常に多く、 単純に移民数に会員の移動が比例しているわけではない。19 世紀末 から 20 世紀初頭にかけて会員数がオーストラリア、南アフリカ、カ ナダの順で増えていることに着目すれば、ゴールドラッシュ (オー ストラリア 1851 年、南アフリカ 1886 年、カナダ 1896 年) の影響や、 蒸気船の就航などが、移動を導く強い要因として考えられるだろう。 断定は難しいが、RIBA 会員数の増減は単なる移民の数のみに従属 するのではなく、ある程度の資本の蓄積があってこそ、RIBA 建築 家たちが群として現れ得たのではないだろうか。

\section{4-3. 第而期}

第III期は、RIBA 全体の会員数とともに海外滞在者数が急増する 1909 年から 1939 年である。どの地域でもまず 1910 年代に会員数 が増加し、1914 年以降減少傾向を見せる。この一時的な減少はヨ ーロッパに近い地域で特に顕著であり、第一次世界大戦による建設 量の減少、会員の戦争への動員が原因であると推測される。そして 1920 年頃から全世界で会員数は再び増加に転じ、1939 年の時点で 会員数が多い上位都市は、オーストラリアのシドニー $(82$ 人)、メル ボルン $(50$ 人)、南アフリカのヨ八ネスブルグ $(66$ 人)、ケープタウ

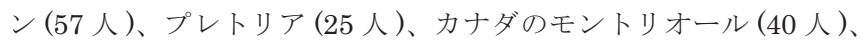
トロント $(21$ 人)、ニュージーランドのウェリントン $(35$ 人 )、オー クランド (32人) となっている。アジアで一番滞在者が多いのはボ ンベイ (56人)で、続いて香港 $(31$ 人)、シンガポール $(29$ 人)、上 海 $(18$ 人) となっている。日本に滞在している会員は東京の 1 人の みで、中国に比べて格段に少ない。これは、日本が東アジアの他の 地域より一足早く西洋式の建築教育に取りかかったことに関係があ る。日本では 1872 年のアルフレッド・ボアンビル、1877 年のコン ドル来日以降日本人建築家の育成に取り組み始め注 37)、1 1886 年には 造家学会が設立され、20 世紀に至る頃には国内での西洋式の建築家 の再生産システムが確立されていた。それに比べて中国国内で西洋 式の建築家教育を施された建築家が育つのは 1920 年代以降と遅く注 38)、中国や海陕植民地における西洋建築の主流は長い間西洋人建築 家・技師たちが握っていた注 39$)$ 。RIBA 会員は東・東南アジアで建築 家の職能を専門分化させることで、さらに自分たちの活動の場を拡 大、確保し、20世紀前半の東・東南アジアでの西洋建築の建設を担 っていったといえる。

図 2 で国別の人数変化に注目寸ると、1910 年代の会員数の急増は、 特にカナダ、南アフリカ、オーストラリア、インド、ニュージーラ ンドで顕著であることがわかる。これらの地域に共通するのは、イ ギリス帝国が支配、影響圈を内陸部にまで広げていたという点であ る。なかでもカナダでの伸びは特異な動きを見せる。この時期のカ
ナダには大陸西部でのゴールドラッシュによる好景気に引き寄せら れて大量の移民が押し寄せており、エドモントン、レジナ、ウィニ ペグ、カルガリー、サスカトゥーンなど、太平洋鉄道沿線の都市建 設が進んだためであると推測できる注 40$)$

1910 年代の全世界での会員数の増加には、もう一つの要因が考え られる。1909 年に始まった有資格会員の募集である。これにより RIBA 会員全体の人数も 1909 年を挟んで 2349 人から 3182 人へと 急増している。同時に全会員に占める海外滞在者の割合も $7 \%$ から $12 \%$ 一と増えていることから、新たに募集された有資格会員が相対 的に多く海外に滞在したものと推測できる。その滞在地に注目して みると 1915 年に海外滞在中の有資格会員 255 人のうち 84 人がカナ ダに、 70 名が南アフリカに、35名がオーストラリアに滞在してい る。さらに彼らの入会時の履歴を調べてみると、これらの会員のう ち 9 割が入会前から現地で建築業に携わっており、彼らは現地の会 員の推薦によって現地で入会したことがわかる。これは逆に言えば、 それ以前の現地社会には、どの建築家団体にも未所属の建築家が、 新たに入会した有資格会員数以上に存在していたということである。 有資格会員の入会条件は、30 歳以上で最低 5 年以上継続してチーフ 建築家として実務に携わった、もしくは最低 10 年以上継続して実務 経験もしくは勉強を積んでいることであった注 41$)$ 。有資格会員は他の 正会員と違って試験合格規定を設けず、それまでRIBAに所属して いなかった実務経験のある有能な建築家の取り込みを図って設けら れた会員区分である注42)。このシステムが、実務経験を積んだ在野の 建築家たちを取り込みながらの RIBA の現地社会への伸長・拡大を 後押したといえるだろう。

以上のように第 III期の会員数の増加は、第 II 期までと同様、自由 移民数との連動に加えて、現地の在野の建築家を取り込みながら RIBA が拡大してきた結果であるといえる。交通手段のさらなる進 歩によって海外滞在者数が増えたばかりでなく、現地の建築家の取 り込みや、現地での建築家としての自らの職の確立、確保、拡大を 通じて、RIBA 会員はさらに世界各地で現地社会へ自らの職能を浸 透させていったのである。

\section{5. 会員の移動}

海外に出た会員の中には、現地で滞在先を変え、複数の都市で建設 活動を行う者もいた。1939 年までに海外に滞在した全 2094 名のう ち、複数都市に滞在した会員は 583 人にのぼる。大多数は近郊都市 間を移動するのみであったが、当時の国境を越えて活動した会員も、 およそ半数の 220 名存在する。移動した会員の滞在先に注目すると、 複数の国を移動した会員 220 名のうち、約 3 分の 1 にあたる 67 名 がヨーロッパ、アメリカ、カナダ、オーストラリア、ニュージーラ ンド間を移動していた。このことから、会員の移動にはある程度の 政治的、言語的、文化的制約が働いていたものと推測される。

図 3 は会員の移動都市数を所属別に分析したものである。第 I 期に 滞在都市を変えた会員は $14 \%$ に満たず、一都市に留まっていた割合 が高い。しかし第 II 期以降は $30 \%$ を超し、同じように複数ヶ国に滞 在した会員は $5 \%$ から $13 \%$ に増えており、年代が下るにつれ、会員 の移動が活発になっていることがうかがえる。

第III期の会員の移動数はさほど第 II 期と変わらないが、複数都市、 複数力国を移動する会員に占める、現地の公的な建設組織 (以下、「政 
府系」とする) の建築家の割合がわずかに増えている。国をまたい で活動した会員ほど政府系建築家である割合が高い傾向にあること がわかる。さらに詳細に分析すると、白人定住地や東・東南アジア での移動と、アフリカなどのその他の地域での移動のパターンには、 異なる特徴がみえてくる。アフリカ内では移動者のうち政府系が半 数を占めるが、白人定住地間と香港・上海・海峡植民地間では民間 の建築事務所所属が 4 分の 3 以上を占めるのである。香港・上海・ 海峡植民地間でのこの状況の背景には、複数都市に支店を持つ大手 建築事務所の存在がある。

例えば、香港には 1868 年にアジアで最も古い民間建築家事務所の ひとつである Palmer\& Turner の前身が開業し、1911 年には上海に 支店を開設している注43)。海峡植民地では 19 世紀半ばまでの建設活 動は東インド会社の軍人技師や素人や職人を中心に行われていたが注 44)、1887 年の市条例によって建築の設計とそれに関する手続きが建 築事務所に任されることになり、後にアジアで最大手の民間建築事 務所のひとつになる Swan\& MacLaren の前身がシンガポールに設 立された 1884 年以降、建築家を抱える民間建築事務所がいくつも 設立された注 45)。Swan\& MacLaren はその後当時の国境を超え、ク アラルンプール、ペナン、バンコク、ロンドンにも支店を開設した。 他にも当時の国境をまたいでシンガポールと上海に支店を持ってい た会社に、Keys\& Dowdeswell がある。また、RIBA 会員が最も多 く滞在していた上海でも、1890 年代から多くの民間建築設計事務所 が設立され、上海を拠点とする大手事務所 Atkinson\& Dallas は天津、 漢口、北京にも支店を広げていた。東・東南アジアに滞在していた 会員の多くはこれらの事務所に所属しており、その支店を移りなが ら建築活動を行う者も多かったことが、上記の傾向につながると考 えられる。

一方、アジアで建築家の職能の確立期にあたる世紀転換期には、こ れらの事務所の所員は必ずしも建築家ばかりではなく、土木技師や 調查師との共同経営の事務所も多数存在していた。例えば Palmer\& Turnerの歴代パートナーは測量士や土木技師が務め、Swan\& MacLaren の創始者の一人は土木技師であり、RIBA 建築家のグル ープと冒険技術者や土木技師の流れを汲む人々の 2 つのグループが 存在していた上海共同租界に拠点を置くAkinson\& Dallas は、土木 技術者の流れを汲んでいる注 46)。しかし第而期以降はこれらの事務所 の共同経営者に RIBA 建築家が就任するケースも増え注 47)、RIBA 建 築家の増加に伴い、建築活動の担い手は徐々に軍人技師や技術者か ら正統な建築家へと移行していく。そして経済的論理で展開される 民間建築事務所の台頭により、政治的領域を超えて都市間を建築家 が移動し、建設活動を行うという段階を迎えたと考えられる。第吕 期は、アジアにおいて政治的枠組みを超えた西洋人建築家の都市間 ネットワークが立ち現われてきた時代であるといえる。

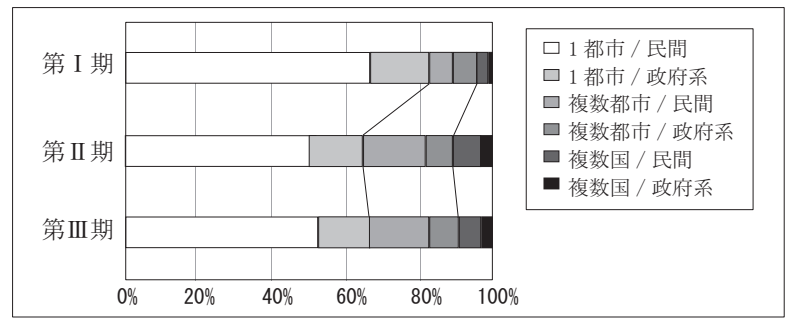

図 3 所属別の移動都市数

\section{6. 結}

本研究ではイギリス本国外に滞在した全 RIBA 建築家をリスト化 し、世界分布やその所属や移動を分析した。

RIBA 建築家たちは、1 1880 年頃までは白人定住地を中心に活動を 行い、1910 年頃まではその中でも特にオーストラリアや南アフリカ で会員数を増やした。しかし 1910 年以降は、非白人定住地、とり わけインドや中国、海峡植民地でも多く活動している。

この会員数の増減は、大きくは本国からの移民数との相関がみられ るが、他にも何点かの影響が考えられる。一つ目は、建築家の職能 と教育の確立をRIBA が担ったことである。イギリス帝国の影響圈 においては、RIBA は近代的な教育制度や職能団体を立ち上げ、自 らを中心に据えながら RIBA 以外の建築世界へ伸長していった。し かしアメリカやヨーロッパのように RIBA に相当する組織が存在す る場所では、移民がいくら多くとも、大きな勢力を確立することは なかった。RIBA は建築家組織として完全に独立して現地社会へ伸 張したのではなく、ある程度政治的な枠組みの中で成長したのだと いえるだろう。二つ目は、ゴールドラッシュや交通網の発展である。 このことから、RIBA 建築家たちが造った建築は、単純に西洋人が 多いところに建てられたわけではなく、それを許容する資本や社会 の成熟などを必要としたであろうことが予想される。三つ目は、東・ 東南アジアにおける大手民間建築事務所の存在である。基本的に白 人定住地内での会員の移動は、政府系、民間系両方の建築家を含ん でいたが、1910 年以降の非白人定住地、とりわけ東アジアや海峡植 民地間では民間の建築家たちの多くが複数都市間を移動しながら活 動していた。政治的領域を超え経済的論理で展開される民間事務所 の出現により、この時期の東アジアと海峡植民地は、RIBA 建築家 にとって一体的な活動の場となっていたといえるだろう。

このように、RIBA 会員は全時代を通して世界一均一に拡大したの ではなく、時代や場所によって異なる論理で移動を導かれていた。 さらに初期においては非白人定住地で活動した会員の多くが若手建 築家であったように、地域によって滞在していた会員の特性も異な る。群で捉えると会員は一見自由に移動しているように見えるが、 その移動には移動先や時代背景に左右された制限が働いていたのだ。

19 世紀から 20 世紀前半の西洋人建築家の多くは、現代の建築世界 の重要な一角を築いてきた。今後は建築家個人に関する研究と、本 研究で得られた世界分布を掛け合わせて、建築家の交流や移動とそ れによって生み出された多くの建築を、広く深く立体的な世界史の 中に位置づけることを目指したい。

\section{参考文献}

1) 水島司編：グローバル・ヒストリーの挑戦, 山川出版社, 2008

2) 秋田茂編: パクス・ブリタニカとイギリス帝国, ミネルヴァ書房, 2004

3)クリストファー, A.: 景観の大英帝国 - 絶頂期の帝国システム, 三嶺書房, 1995

4)Gotch, J. A.: The Growth and Work of the Royal Institute of British Architects 1834-1934, Simon and Co., 1934

5)Mace, Angela: The Royal Institute of British Architects-A Guide to its Archives and History, Mansell Publishing, 1986

6) ジェンキンス，フランク：建築家とパトロン -16 世紀から現代までの建築家 の職能と実務の史的研究, 佐藤彰・後藤利兵衛訳, 鹿島出版, 1977

7) コルトフ, スピロ : 建築家 - 職能の歴史, 槙文彦訳, 日経マグロウヒル社, 1981

8) Crinson, Mark: Modern Architecture and the End of Empire, Ashgate, 
2003

9)Anderson, J. Macvicar: Opening Address, RIBA Journal 3rd Ser., vol.1, 1893

10) ポーター,アンドリュー：大英帝国歴史地図 -イギリスの海外進出の軌跡, 横井勝彦・山本正訳, 東洋書林, 1996

11)Elliot, Cecil D.: The American Architecture from Colonial Era to the Present, McFarland, 2003

12) 澤喜司郎：東洋航路への蒸気船の進出と定期航路の開設（II ·完）一イギ リス定期汽船会社 P.\&O. 社の成立と発展を中心に, 東覀経済研究, Vol.49. pp71-114, 1981

13) 山田史郎, 北村暁夫, 大津留厚, 藤川隆男, 柴田英樹ら：近代ヨーロッパの 探求 1 - 移民, ミネルヴァ書房, 1998

14)Johnson, Chris: Public Architecture in a Changing World-Sydney's Progression from Imported Architecture to Local Identity, Architectural Theory Review, Vol.2, No.2, pp29-40, 1997

15) 藤森照信：日本の近代建築 - 幕末 ・明治篇, 岩波新書, 1993

16) Seow, Eu Jin: Architectural Development in Singapore, Ph.D. thesis, University of Melbourne, 1973

17) 藤森照信, 汪坦 : 全調査 - 東アジア近代の都市と建築, 大成建設, 1996

18)Palmer and Turner: Tall Storeys-Palmer and Turner Architects and Engineers- The First 100 years, Palmer and Turner, 1985

19)Billimoria, H. J.: The Origin and Growth of the Indian Institute of Architects, Journal of the Indian Institute of Architects, pp203-210, 1942

20)Liu, Gretchen, Lloyd,R. Ian: Pastel Portraits-Singapore's Architectural Heritage, Singapore Coordinating Commitee, 1999

21)Edwards, Norman: The Singapore House and Residential Life 18191939, Oxford University Press, 1990

22) 村松伸：上海：都市と建築 1842-1949 年, PARCO 出版局, 1991

23) Bridges Peter, McDonald, Don: James Barnet Colonial Architect, Hale and emonger Pty Limited,Sydney,1988

24）井野瀬久美惠：大英帝国という経験，興亡の世界史 16, 講談社, 2007

\section{注}

注 1) 参考文献 $1, \mathrm{p} 91$

注 2) 帝国の概観については、参考文献 2, pp1-11 と参考文献 3 による。

注 3) イギリス本国内、海外の分類は、RIBA Kalender の名簿における分 類に従う。Kalenderでは会員の滞在地が大きく United Kingdom と Abroad に分類されている。Abroadには、インドや南アフリカなどの植民 地 (colonies), 属領 (dependencies), カナダやオーストラリアなどの自治領 (dominions), アメリカや日本などの海外 (foreign countries) が含まれる。ア イルランドもスコットランドも United Kingdom に含まれているため, 今回 は両者ともイギリス本国の一部として扱う。

注 4) 会員名簿は 1835 年と 1842 年は Transaction 1 st series,1849 年から 1885 年は RIBA Proceedings 1 st series, 1886 年以降は RIBA Kalendarに 掲載されたものを利用した。ただし会員名簿掲載のなかった 1878 年, 1885 年,1918 年は名簿を作成していない。名簿は全ての会員を網羅していると判 断できるが, 会員になるには年齢制限, 実務経験や試験への合格が必要なた め, 会員の中には名簿に載る以前から海外に滞在している場合がある。会員 数の分析に際しては会員名簿掲載のデータを用いる。

注 5)RIBA の会員にはいくつかの区分がある。1837 年の憲章には, 正会員 (Subscribing Member)としてフェロー会員 (Fellow), 準会員 (Associate), 名誉準会員 (Honorary Associate) があげられ, 非正会員 (Non Subscribing Member) として名誉フェロー会員 (Honorary Fellow) と名誉客員会員 (Honorary Corresponding Member) があげられている。1909 年から 1955 年までは有資格会員 (Licentiate) も設けられた。

注 6) 参考文献 4,5

注 7)Brown, Sally May: Architects and Others-an annoted list of people of South African interest appearing in the Royal Institute of British Architects Journal 1880-1925- A Bibliography, Johannesburg: University of Witwatersrand, 1969

注 8) 泉田英雄: ブラントン、マクヴィン、そしてボアンビルについて・イギ リス系技術者の系譜その 1 , 日本建築学会近畿支部研究報告集, pp897-900, 1990/ 泉田英雄: イギリス領事館及び外交施設建築とクロスマン 東アジアの イギリス系技術者の系譜その 2 , 日本建築学会東北支部研究報告集, pp 31 -
34, 1990/ 泉田英雄 : 19 世紀半ばから 20 世紀にかけての RIBA 会員建築家 の活動 - アジアのイギリス人技術者の系譜その 3 , 日本建築学会東海支部研 究報告集, pp853-856, 2002/ Izumida, Hideo: A Study on British Architects in East and Southeast Asia, Journal of Asian Architecture and Building Engineering, Vol. 2, No. 2, 2003

注 9) オーストラリアの都市計画の父と称されるJohn Sulmanに関して は Edwards, Zenaida: The Life and Works of John Sulman 1849-1934, University of Technology, 2006, シドニーで多数の建築を手がけた James Barnetに関しては Bridges, Peter, McDonald, Don: James Barnet Colonial Architect, Hale and Iremonger, 1988, ニュージーランドの最初の建築家と される William Masonに関しては Stacpoole, John: William Mason-The First New Zealand Architect, Oxford University Press, 1971, 南アフリカ やインドで政府系建築家として活動した Herbert Baker については Greig, Doreen: Herbert Baker in South Africa, Purnell, 1970, カナダで建築教育 に携わった Percy Erskin Nobbsに関しては Murray, Irena: Percy Erskin Nobbs and His Associates, McGill University, 1986 などがある。 注 10）実際は1837 年から Royal Institute of British Architects と自称。

注 11) 参考文献 $6, \mathrm{p} 245$

注 12) 参考文献 7, p200

注 13) 参考文献 6, ,p125

注 14)RIBA の憲章 (Royal Charter) による。

注 15) 参考文献 5,p16

注 16) 参考文献 $6, \mathrm{p} 189$

注 17) 参考文献 $8, \mathrm{p} 44$

注 18) 参考文献 $7, \mathrm{p} 211$

注 19) 参考文献 $8, \mathrm{p} 45$

注 20)RIBA の 1887 年の規則 (By Laws)による。

注 21) 参考文献 $5, \mathrm{p} 283$

注 22) 参考文献 $9, \mathrm{p} 4$

注 23）第二次世界大戦終了の 1945 年までの Kalender のうち、会員名簿が記

載されているのは 1939 年までであるため、分析は 1939 年までとする。

注 24) 参考文献 $10, \mathrm{p} 88$

注 25）参考文献 $11, \mathrm{pp} 42-45$

注 26)Monte Video; ウルグアイの都市, Valparaiso; チリの都市

注 27)Selangor; マレーシアの都市

注 28) 参考文献 12

注 29）例えば W. サルウェイ,W. キドナー, W.D. ベイリスに代表されるように 初期に香港，上海，シンガポールにやってきた会員のほとんどが民間建築家 であった。人数については図 3 を参照。

注 30$)$ 生年月日の分かった 32 人のデータを用いた。

注 31）参考文献 $10, \mathrm{p} 75$

注 32 ) 参考文献 $13, \mathrm{p} 133$

注 33）参考文献 14 例えばこの時期のシドニーの植民地建築課は 1000 以上の 建築を手がけている。RIBA 会員である J. バーネットはそのうちのほとん どの公共建築の責任者となり，オーストラリア博物館，シドニー中央消防署 などの設計を手がけた（参考文献 23)。

注 34) 参考文献 $13, \mathrm{p} 133$

注 35) 参考文献 $10, \mathrm{p} 79$

注 36) 参考文献 $10, \mathrm{p} 88$

注 37) 参考文献 $15, \mathrm{p} 169$ など

注 38) 参考文献 $17, \mathrm{p} 145$

注 39）中国に関しては参考文献 $17, \mathrm{pp} 13-17$ ，海峡植民地に関しては参考文献 16,pp77-105

注 40）例えばマニトバ州の州都であるウィニペグは、カナダの東部と西部を結 ぶ鉄道の重要な結節点であるが、1 870 年にカナダに組み込まれた後、人口 は 20 年間で 100 倍以上増加した (参考文献 $24, \mathrm{p} 126$ )。この都市でカナダ 北部鉄道の建築部門に従事していた RIBA 会員に A.W. ウィーラーがいる。 注 41)RIBAの 1925 年の増補憲章 (Supplemental Charter)による。

注 42) 参考文献 $4, \mathrm{p} 36$

注 43) 参考文献 $16, \mathrm{p} 84$

注 44) 参考文献 19, p203, 参考文献 20, p19

注 45) 参考文献 $21, \mathrm{p} 225$

注 46) 参考文献 $22, \mathrm{p} 118$

注 47）例えば Swan\&MacLaren のペナン支店は 1921 年から 30 年まで RIBA

会員 D.M. クライクによって運営され, Palmer\&Turner の上海支店は RIBA 会員 G.L. ウィルソンによって運営されていた。 